\title{
Willingness of farmers to establish a renewable energy (solar and wind) cooperative in NW Turkey
}

\author{
Bengü Everest ${ }^{1}$
}

Received: 11 March 2020 / Accepted: 10 March 2021 / Published online: 15 March 2021

(C) Saudi Society for Geosciences 2021

\begin{abstract}
This study was conducted to investigate farmers' desire to benefit from renewable energy (solar and wind) in northwestern provinces in Turkey. The willingness of farmers to establish a renewable energy cooperative was also investigated in this study. The relationships between the socioeconomic characteristics of the farmers and their willingness to establish a renewable energy cooperative were analyzed with the aid of nonparametric tests. According to Mann-Whitney $U$-test, farmers' age, frequency of visits to agricultural organizations, internet use to reach information, land size, and the province where they live were effective on farmers' willingness to establish a renewable energy cooperative. Additionally, $91.34 \%$ of the participant farmers were worried about climate change, and $70.84 \%$ were willing to receive training about climate change. Of the participant farmers, $65.88 \%$ were willing to establish a renewable energy cooperative. Extension programs should be organized by policymakers about renewable energy cooperatives, and such programs will provide significant public benefits.
\end{abstract}

Keywords Climate change $\cdot$ Renewable energy $\cdot$ Cooperative $\cdot$ Farmer $\cdot$ Willingness $\cdot$ Turkey

\section{Introduction}

According to Intergovernmental Panel on Climate Change (IPCC), climate change is a worldwide problem for all countries regardless of their development levels (IPCC 2014). Various policies have been implemented to combat climate change, a global problem. For instance, climate action is among the sustainable development goals of the United Nations Development Programme (UNDP). Another goal also emphasizes accessible and clean energy (UNDP 2019).

Turkey is a Mediterranean Basin country and is vulnerable to the impact of global climate change (Karaca and Nicholls 2008). Turkey's total greenhouse gas emissions were 219.4 $\mathrm{CO}_{2}$ equivalent in 1990 , while the $520.9 \mathrm{CO}_{2}$ equivalent was recorded in 2018 (Turkish Statistical Institute 2020a). Turkey still meets most of the energy demands from fossil fuels (Topcu et al. 2019; Rincon et al. 2019). For example, electricity generation in Turkey was provided at rates of $37.3 \%$ from

Responsible Editor: Amjad Kallel

Bengü Everest

beverest@comu.edu.tr

1 Faculty of Agriculture, Department of Agricultural Economics, Çanakkale Onsekiz Mart University, 17020 Çanakkale, Turkey coal, $29.8 \%$ from natural gas, $19.8 \%$ from hydraulic energy, $6.6 \%$ from wind, $2.6 \%$ from the Sun, $2.5 \%$ from geothermal energy, and $1.4 \%$ from other sources in 2018 (Republic of Turkey Ministry of Energy and Natural Resources 2020); $6.5 \%$ of the produced electricity in Turkey was used in agriculture, animal husbandry, and fishing activities (Turkish Statistical Institute 2020b). Despite the low sectoral share of total energy use in agriculture, Turkey's concerns about global warming and climate change have increased interest in agricultural energy efficiency, as in many countries around the world (Beyaz et al. 2017). Therefore, as in other sectors, there are measures to be taken in the agricultural sector. The most significant actions in Turkey to combat climate change include increasing the ratio of renewable energy in electrical energy production, improving energy efficiency, carbon sequestration and storage technologies, afforestation, and natural carbon sink areas (Republic of Turkey Ministry of Energy and Natural Resources 2019). Turkey has quite a high renewable energy potential (Çetin and Eğrican 2011; Topkaya 2012; Melikoglu 2016; Büyüközkan and Güleryüz 2017). On the other hand, Turkey is an energy-importing country, and this case brings about financial problems like currency outflow (Kaygusuz and Türker 2002). The Turkish government should also take firm action for the development of clean and renewable energy sources (Bilgen et al. 2015). Considering 
structural problems in the agricultural sector (Yavuz 2005; Günaydın 2010; Çetin 2008; Dinler 2008), it was thought that cooperatives would provide more advantages in using renewable energy (Bilgin and Akçay 2017; Gürel and Irmak 2017; Uslu and Kedikli 2017). The United Nations declared 2012 the Year of International Cooperatives. In addition, the United Nations declared 2012 as the Year of Sustainable Energy. Thus, the concepts of energy and cooperatives have been mentioned together in recent years. The aims of cooperatives are to ensure the social and economic development of their partners (Everest 2018), to contribute to production (Soboh et al. 2012), to contribute to employment (Craig and Pencavel 1993), and to contribute to marketing (McBride 2012). Cooperatives are successfully operated in almost every sector. The goal of energy cooperatives was fixed as producing electrical energy from renewable energy sources in accordance with the regulations of the electricity market to meet the electric energy needs of cooperative members (Republic of Turkey Ministry of Trade 2017). The energy cooperative phenomenon is still very new, and there is a lack of research on this subject (Yildiz and Radtke 2015). Changes in energy policies due to the oil crisis that occurred in the 70s, environmental problems that began to pose a threat to human existence, and increasing energy prices brought together environmentally sensitive citizens and enabled them to cooperate in the field of renewable energy (Durmaz Ayanoğlu 2014). Recently, cooperatives were established to promote the use of renewable energy, particularly in Canada, USA, UK, Denmark, and Germany (Viardot 2013). Energy cooperatives organize energy production and can also influence energy price movements (Yildiz et al. 2015). Energy cooperatives create a different model of energy supply and distribution, unlike "end-of-wire captive consumers" (Schreuer and Weismeier-Sammer 2010). Also, some of the business objectives of energy cooperatives can be listed as energy generation, implementation and operation of small district heating systems, energy marketing and trading, marketing and installation of energy technology, operation of an electricity grid, acquisition, or marketing of biomass, lobbying and networking, and research and development (Debor 2014). However, the number of renewable energy production cooperatives is quite limited in Turkey. There are 47 renewable energy cooperatives in Turkey, and only six of them are producing electricity (Yıldırım 2020). Therefore, electric power generation from renewable energy sources through cooperatives is a new issue for Turkey (Anonymous 2020). For the establishment of renewable energy cooperatives in Turkey, social awareness needs to be created (Durmaz Ayanoğlu 2014). The use of renewable energy in the agricultural sector provides a few benefits to farmers. In addition to environmental impacts, the use of renewable energy also contributes economically to farmers. Electricity is used in agricultural activities such as irrigation, milking, animal shelters and greenhouses, lighting, heating, ventilation, and cooling (Beyaz et al. 2017). In addition, it was reported that the use of renewable energy by cooperatives provides benefits (Bender 1999; Zoellner et al. 2008; Li et al. 2013; Viardot 2013; Hufen and Koppenjan 2015; Al Katsaprakakis and Voumvoulakis 2018; Capellán-Pérez et al. 2018; Hentschel et al. 2018; Paredes and Loveridge 2018; Fang and Yang 2019; Li et al. 2019; Roesler and Hassler 2019).

Nowadays, the fight against climate change continues.,because (1) with the COVID-19 pandemic, the agricultural sector gained importance, (2) the food supply of humans remains an important issue, (3) the renewable energy is getting attention worldwide, and (4) farmers and companies can invest individually or collectively in the use of renewable energy. But collective investments in the form of cooperatives offer some advantage over individual investments. Therefore, it is important for farmers to benefit from renewable energy through cooperatives in the climate-agriculture-environment-energy axis. Investments in renewable energy are initially costly (Angelopoulos et al. 2017). But with the rapid costs decreasing in the wind and solar energy, renewable electricity has become the preferred source of power generation over the past few years (Motyka et al. 2018). According to the International Renewable Energy Agency (IRENA), renewable energy has entered a virtuous cycle of decreasing costs, increasing deployment, and accelerated technological progress. Solar photovoltaic (PV) module prices have decreased by around $90 \%$ since the end of 2009 , and wind turbine prices have decreased by 55-60\% since 2010. In Turkey, weighted average-levelized cost of energy (LCOE) utility-scale solar PV projects are as follows: 2016 module costs: 2019 USD/kWh: 0.11260; 2017 module costs: 2019 USD/kWh: 0.10720; 2018 module costs: 2019 USD/kWh: 0.08540; 2019 module costs: $2019 \mathrm{USD} / \mathrm{kWh}: 0.07760$.

In addition, the weighted average LCOE of newly commissioned onshore wind projects by Turkey is as follows: 2016 module costs: 2019 USD/kWh: 0.06500; 2017 module costs: 2019 USD/kWh: 0.05900; 2018 module costs: 2019 USD/ kWh: 0.06600; 2019 module costs: 2019 USD/kWh: 0.06300 (IRENA 2020). However, higher interest rates in developing countries such as Turkey have negatively affected investment in renewable energy (Gürtürk 2019). Therefore, using energy generated from solar or wind for farmers may initially seem costly compared to purchasing electricity from the grid. However, this cost can be minimized with strong incentive systems. After the first investment, using renewable electricity can be cheaper than using electricity from the grid. The use of renewable energy by farmers is an important issue; therefore, farmers' approaches should be examined. For this purpose, farmers were asked whether they would like to establish a renewable energy cooperative. To the best of author's knowledge, there were no previous studies about farmers' willingness to establish a renewable energy cooperative. That makes this study unique. 


\section{Materials and methods}

\section{Study area}

The study area is located in the Marmara region (NW Turkey), covering the provinces of Balıkesir and Çanakkale. The study area borders the Aegean Sea in the west, the Marmara Sea in the north, the Aegean Region in the south, and the Marmara region in the east (Fig. 1).

\section{Data collection and analysis}

Two methods were used in this study for data collection. First, the literature was reviewed. For this, a comprehensive literature review was carried out in Scopus, Web of Science, and Google Scholar. Keywords used included the willingness to pay, awareness of renewable energy, acceptance, adaptation, and agriculture plan as renewable energy. Additional data were gathered through a questionnaire study. The questionnaire form consisted of three parts. The first part of the questionnaire included questions about the demographic characteristics of the farmers, and the second part included questions about agricultural structure. In the last section, farmers' concerns about climate change and their willingness to cooperate about renewable energy use were investigated. In order to measure the desire of farmers to cooperate in relation to renewable energy, studies in the literature were used to measure the approaches of consumers and local participants to renewable energy (Batley et al. 2001; Borchers et al. 2007; Ek 2005; Ma et al. 2015; Roe et al. 2001; Soon and Ahmad 2015). For this purpose, farmers were asked whether they would like to cooperate about renewable energy. The survey was conducted through face-to-face meetings with the farmers. The rational sampling method was used to determine the number of farmers to be interviewed (Newbold 1995). While determining the sample volume, the $95 \%$ confidence interval and 5\% margin of error were used, and the sample volume was calculated with the aid of the following equation as 381. The sample volume obtained was distributed proportionally between farmers in Balıkesir and Çanakkale provinces. Then, questionnaires were applied to 256 farmers in Balıkesir and 125 farmers in Çanakkale provinces.

Fig. 1 Study area

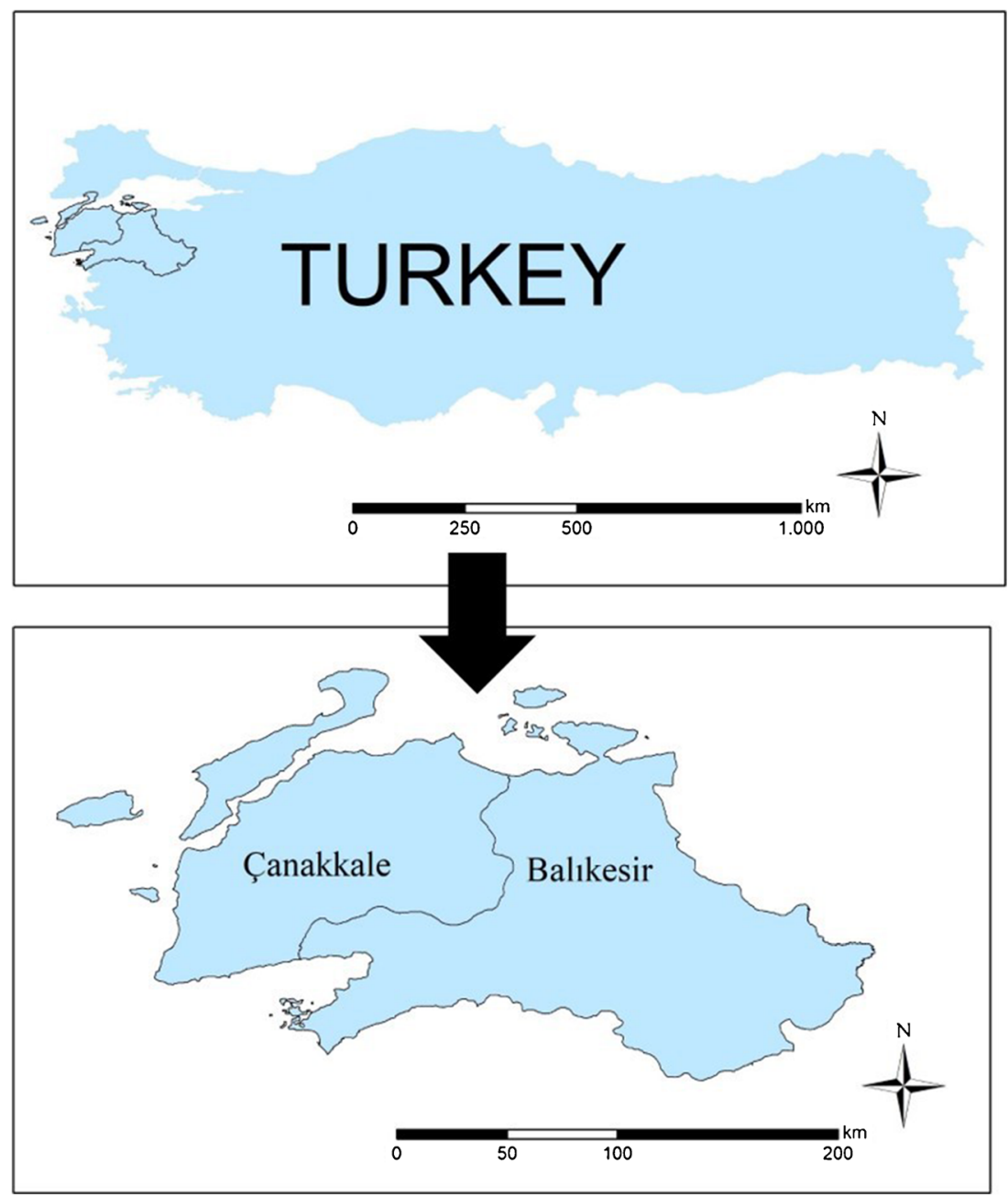




$$
\begin{gathered}
n=\frac{N * p * q}{(N-1) * \sigma^{2} p+p * q}=\frac{61,509 * 0.5 * 0.5}{(61,509-1) * 0.00065+(0.5) *(0.5)}=381 \\
\sigma^{2} \mathrm{p}=\left(r / \mathrm{Z}_{\alpha / 2}\right)=(0.05 / 1.96)^{2}=0.00065
\end{gathered}
$$

where $n$ is the sample size, $N$ the population size, $\sigma^{2}$ the variance of rate, $r$ the allowable margin of error $(5 \%), Z_{\alpha / 2}$ the $\mathrm{Z}$ ruler value, and $p$ the probability of occurrence of the investigated event.

Statistical methods were determined based on whether the data were parametric. Data normality was checked with the aid of the Shapiro-Wilk test. The present analysis revealed that data were not normally distributed $(p<0.05)$. In other words, the data were not parametric. Thus, nonparametric tests were used for statistical assessments. Initially, demographic characteristics and agricultural structures of the farmers were expressed in numbers and proportion basic statistics. MannWhitney $U$-test (Mann and Whitney 1947) and KruskalWallis $H$-test (Kruskal and Wallis 1952) were used to analyze farmers' desires to organize about renewable energy.

\section{Results and discussion}

\section{Socioeconomic characteristics of the farmers}

Age and educational level of the farmers, frequency of visits to agricultural organizations to access agricultural information, use the internet to access agricultural information, land size of agricultural enterprises, annual incomes, and provinces where they live are presented in Table 1.

As can be inferred from Table 1, 34.38\% of the participant farmers were considered young farmers within the age range of 18-45 years. This was followed by the middle-age group (46-64 years, 56.69\%) and old farmers (over 65 years, $8.92 \%$ ). Of the participant farmers, $73.75 \%$ had primary or secondary school education levels. The rest $(26.25 \%)$ were composed of high school or university graduates. These education levels indicated that farmers in research had quite low educational levels. With regard to visits to agricultural organizations like Directorates of Agriculture and Forestry, chamber of agriculture, and cooperatives, $48.82 \%$ of the participant farmers indicated that they frequently visited agricultural organizations, $18.37 \%$ indicated that they visited these organizations from time to time, and $32.81 \%$ indicated that they visit such organizations rarely. Of the participant farmers, $61.42 \%$ used the internet to reach information. However, there is still a large group (38.58\%) in the region who do not use the internet. The average land size in the research site was 71 decare (da). This number is slightly higher than the average for Turkey (61 da). About $65 \%$ of the farmers had a land size lower than the average land size of $71 \mathrm{da}$. With regard to the annual income of farmers from agricultural activities, $22.57 \%$ had an annual income lower than 10,000 TRY (Turkish lira),
$24.41 \%$ had an income of between 10,001 and 20,000 TRY, $16.01 \%$ had incomes of between 20,001 and 30,000 TRY, $10.24 \%$ had incomes of between 30,001 and 40,000 TRY, $10.76 \%$ had incomes of between 40,001 and 50,000 TRY, and $16.01 \%$ had annual incomes over 50,001 TRY. These numbers indicated that farmers in the research area were within the middle-income group. Of the participant farmers, $67.19 \%$ lived in Balıkesir province, and $32.81 \%$ lived in Çanakkale province.

\section{Farmers' awareness of climate change and renewable energy}

Participant farmers were asked whether they were worried about climate change. They were also asked whether they were willing to receive training on how to combat climate change; $91.34 \%$ of the participant farmers were worried about climate change (Fig. 2).

\begin{tabular}{|c|c|c|}
\hline Characteristics & Number $(n)$ & Rate $(\%)$ \\
\hline \multicolumn{3}{|l|}{ Age (year) } \\
\hline $18-45$ & 131 & 34.38 \\
\hline $46-65$ & 216 & 56.69 \\
\hline$>65$ & 34 & 8.92 \\
\hline \multicolumn{3}{|l|}{ Education } \\
\hline Primary or secondary school & 281 & 73.75 \\
\hline High school or university & 100 & 26.25 \\
\hline \multicolumn{3}{|l|}{ Visit agricultural organizations } \\
\hline Frequently & 186 & 48.82 \\
\hline Sometimes & 70 & 18.37 \\
\hline Rarely & 125 & 32.81 \\
\hline \multicolumn{3}{|c|}{ Use of internet to reach information } \\
\hline Using & 234 & 61.42 \\
\hline Not using & 147 & 38.58 \\
\hline \multicolumn{3}{|l|}{ Land size (da) } \\
\hline$\leq 71$ & 227 & 64.86 \\
\hline$>71$ & 123 & 35.14 \\
\hline \multicolumn{3}{|l|}{ Annual income $(T R Y)^{a}$} \\
\hline$<10,000^{\mathrm{b}}$ & 86 & 22.57 \\
\hline $10,001-20,000$ & 93 & 24.41 \\
\hline $20,001-30,000$ & 61 & 16.01 \\
\hline $30,001-40,000$ & 39 & 10.24 \\
\hline $40,001-50,000$ & 41 & 10.76 \\
\hline$>50,001$ & 61 & 16.01 \\
\hline \multicolumn{3}{|l|}{ Province } \\
\hline Balıkesir & 256 & 67.19 \\
\hline Çanakkale & 125 & 32.81 \\
\hline
\end{tabular}

Table 1 Profile characteristics of farmers

${ }^{\mathrm{a}}$ Approx 1 TRY $=$ US $\$ 0.14 .{ }^{\mathrm{b}}$ Minimum wage 
Fig. 2 Farmers' approaches to climate change
Worry about climate change

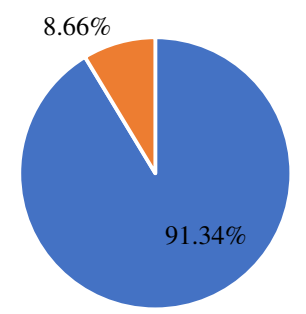

- Worried $\quad$ - Not worried
Willingness to take training on climate change

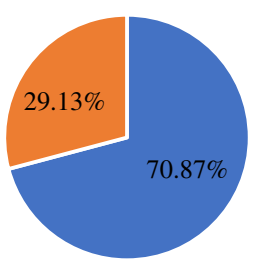

- Willing - Not willing
Farmers' perceptions about renewable energy sources, especially about solar and wind energy, were investigated. Initially, farmers' use of solar and wind energy was taken into consideration. Then, the farmers' desire to use solar and wind energy was questioned (Fig. 3). In a study conducted in the UK, it was reported that $30 \%$ of farmers used solar energy, $28 \%$ used biomass energy, and $13 \%$ used wind turbines (Tate et al. 2012). According to Wüstenhagen et al. (2007), adaptation strategies should urgently be considered for successful implementation of renewable energy policies. Of the participant farmers, $85.32 \%$ were willing to use solar energy and $81.69 \%$ were willing to use wind energy in their agricultural activities (Fig. 2). Despite the low current use ratios, most participant farmers were willing to use solar and wind energy. This high willingness should be taken into consideration by decision makers and policymakers to increase renewable energy (RE) utilization ratios.

In recent years, cooperatives played a significant role in renewable energy utilization (Downing et al. 2005; Viardot 2013). Therefore, participant farmers were asked about whether they wished to organize in relation to renewable energy; in other words, whether they were willing to establish a renewable energy cooperative (Fig. 4). As can be inferred from Fig. 4, $65.88 \%$ of participant farmers were willing to establish a renewable energy cooperative. The necessity of establishing renewable energy cooperatives was reported in previous studies. For instance, in a study conducted in the USA, personal, cooperative, and state projects for renewable energy use were assessed. Each one of them had different competitive powers, and selection of a certain structure (personal, cooperative, and state) was totally dependent on available conditions (Bolinger and Wiser 2006). It was also reported that renewable energy projects could be managed better by cooperatives rather than profit-oriented private companies. This was because of good community participation in cooperatives (Subbarao and Lloyd 2011). Also, consumers are willing to pay more for renewable energy through cooperatives. This is due to democratic decision making, which is a distinctive feature of cooperatives (Sagebiel et al. 2014). In general, farmers want to benefit from wind and solar energy at high rates. In addition, $65 \%$ of them want to cooperate for renewable energy. So why do farmers not establish a cooperative despite their enthusiasm for
Fig. 3 Farmers' use and willingness to use solar and wind energy

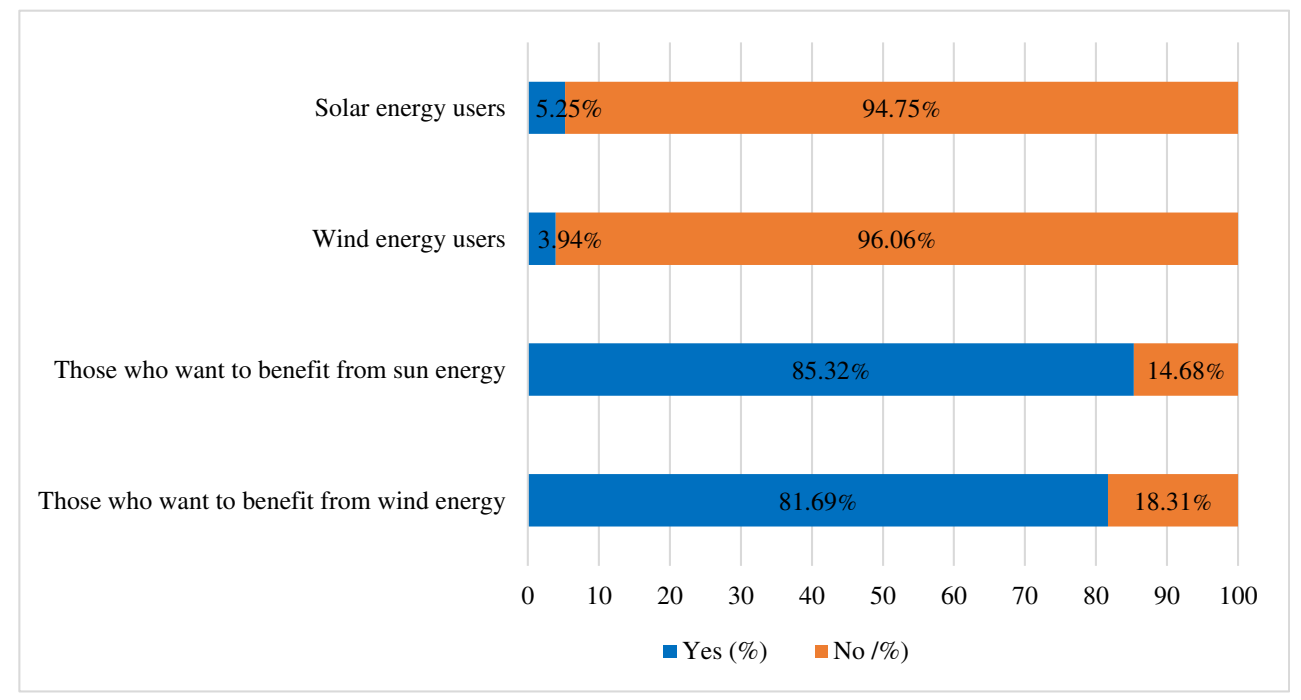


Willingness to establish a cooperative

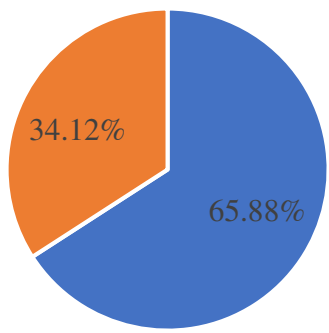

-Willing $\quad$ Not willing

Fig. 4 Farmers' willingness to establish a renewable energy cooperative

renewable energy? For this reason, it is important to discuss what the drivers and barriers are for establishing a renewable energy cooperative.

\section{Drivers and barriers for establishing a renewable energy cooperative}

Renewable energy investments are costly and must involve solidarity with key national energy stakeholders, including policymakers, project developers, investors, equity providers, bankers, and energy analysts. The three most important components of RE investments are policy design, financing, and social acceptance (Angelopoulos et al. 2017). In this context, farmers are willing in terms of the social acceptance component. However, it is not enough for farmers to be willing. Farmers are also required to provide equity capital for renewable energy investments. This is related to the farmers' income. The presence of structural problems in the agricultural sector in Turkey is a known fact. For example, small and scattered agricultural land, high input prices, and marketing problems are the first problems that come to mind. In addition, the low level of education and low income of farmers should be considered. Therefore, the agricultural sector requires more finance. Policies to be implemented to increase farmers' income will also increase the use of renewable energy. On the other hand, the use of renewable energy will also increase farmer's income. In other words, participants and policymakers should act together to achieve this goal. This approach is also called the win-win strategy (WWS) in the literature (Meissner et al. 2020). There are important differences in the renewable energy potential and its usage in Turkey. Because renewable energy investment costs are high, and there are difficulties in the renewable energy investment legislation, which allow participation by especially large masses. Financial and technological constraints are at the top of the list of these difficulties. For example, although different incentive systems are needed to increase domestic production and benefit from solar energy, financial conditions should be improved. Banks need to regulate the collateral conditions, and insurance companies need to adjust policy conditions. In addition, problems arising from bureaucratic procedures in the sector must be eliminated. A qualified workforce is also needed in the sector. Various arrangements and training should be held with this aim (Karagöl and Kavaz 2017). Financial constraints and technological deficiencies also create obstacles in utilizing wind energy. In addition, the main problems facing wind energy and electricity generation are that some projects cannot be realized due to forest permits, expropriations cannot progress with the decision to suspend execution in some projects, and bureaucratic obstacles cannot be reduced (Karagöl and Kavaz 2017). Socioeconomic factors play an important role in adapting to an innovation (Mwirigi et al. 2009). Therefore, socioeconomic factors effective on farmers' willingness to establish a renewable energy cooperative were analyzed, and results were given in Table 2 .

As can be inferred from Table 2, farmers' willingness to establish a renewable energy cooperative was influenced by their age, frequency of visits to agricultural organizations, using internet to reach information, land size, and the province where they lived. Educational levels and annual agricultural incomes were not found to be significant. Farmers' age was indicated as an effective factor in adaption of renewable energy (Tate et al. 2012). In this study, age was identified as a distinctive factor in farmers' willingness to establish a cooperative for energy production from the sun or wind $\left(\chi^{2}=34.584, d f 2, p=0.000\right)$. Frequency of visits to agricultural organizations was also a distinctive factor in farmers' willingness to establish a renewable energy cooperative $\left(\chi^{2}=7.516\right.$, $d f 2, p=0.023)$. Using internet to reach information was also identified as a distinctive factor in farmers' willingness to establish a renewable energy (solar or wind) cooperative ( $M W-U=15,415.5, z=-1.977, p=0.048)$. A previous study conducted in the USA with California farmers indicated that internet access was a distinctive factor in adaption of renewable energy sources (Beckman and Xiarchos 2013). Land size was also indicated to be a distinctive factor in adaption of renewable energy sources by farmers (Panoutsou 2008; Tate et al. 2012; Borchers et al. 2014). In this study, land size was identified as a distinctive factor in farmers' willingness to establish a renewable energy cooperative $(M W-U=15415.5$, $z=-1.977, p=0.023$ ). The province where the farmers lived was again identified as a significant factor in farmers' willingness to establish a renewable energy cooperative ( $M W$ $U=10177.5, z=-5.942, p=0.000)$. Based on these findings, it can be stated that farmers' willingness to establish a renewable energy cooperative was different in Balıkesir and Çanakkale provinces. Education was the most distinctive factor for farmers' awareness of climate change (Lee et al. 2015; Korkmaz 2018; Yayar et al. 2014). Well-educated individuals have greater awareness about climate change (Waibel et al. 
Table 2 Comparison of farmers' willingness to form renewable energy cooperatives by their socioeconomic factors

\begin{tabular}{|c|c|c|c|c|}
\hline Variables & $n$ & Test results & & \\
\hline \multicolumn{5}{|l|}{ Age (year) } \\
\hline $\begin{array}{l}18-45 \\
46-65\end{array}$ & $\begin{array}{l}131 \\
216\end{array}$ & \multirow[t]{2}{*}{$\chi^{2 * *}=34.584$} & \multirow[t]{2}{*}{$d f=2$} & \multirow[t]{2}{*}{$p=0.000 * * *$} \\
\hline$>65$ & 34 & & & \\
\hline \multicolumn{5}{|l|}{ Education } \\
\hline $\begin{array}{l}\text { Primary or secondary school } \\
\text { High school or university }\end{array}$ & $\begin{array}{l}281 \\
100\end{array}$ & $M W-U^{*}=12744.0$ & $z=-1.602$ & $p=0.109$ \\
\hline \multicolumn{5}{|c|}{ Frequency of visit to agricultural organizations } \\
\hline $\begin{array}{l}\text { Frequently } \\
\text { Time to time }\end{array}$ & $\begin{array}{l}186 \\
70\end{array}$ & \multirow[t]{2}{*}{$\chi^{2 * *}=7.516$} & \multirow[t]{2}{*}{$d f=2$} & \multirow[t]{2}{*}{$p=0.023 * * *$} \\
\hline Rarely & 125 & & & \\
\hline \multicolumn{5}{|c|}{ Use of internet to reach information } \\
\hline $\begin{array}{l}\text { Using } \\
\text { Not using }\end{array}$ & $\begin{array}{l}234 \\
147\end{array}$ & $M W-U^{*}=15415.5$ & $z=-1.977$ & $p=0.048 * * *$ \\
\hline \multicolumn{5}{|l|}{ Land size (da) } \\
\hline $\begin{array}{l}\leq 71 \\
>71\end{array}$ & $\begin{array}{l}227 \\
123\end{array}$ & $M W-U^{*}=9137.5$ & $z=-2.279$ & $p=0.023 * * *$ \\
\hline \multicolumn{5}{|l|}{ Annual income (TRY) } \\
\hline $\begin{array}{l}<10,000 \\
10,001-20,000\end{array}$ & $\begin{array}{l}86 \\
93\end{array}$ & \multirow[t]{5}{*}{$\mathrm{X}^{2 * *}=7.098$} & \multirow[t]{5}{*}{$d f=5$} & \multirow[t]{5}{*}{$p=0.213$} \\
\hline $20,001-30,000$ & 61 & & & \\
\hline $30,001-40,000$ & 39 & & & \\
\hline $40,001-50,000$ & 41 & & & \\
\hline$>50,001$ & 61 & & & \\
\hline \multicolumn{5}{|l|}{ Province } \\
\hline $\begin{array}{l}\text { Balıkesir } \\
\text { Çanakkale }\end{array}$ & & $M W-U^{*}=10177.5$ & $z=-5.942$ & $p=0.000 * * *$ \\
\hline
\end{tabular}

*Mann-Whitney $U$-test, **Kruskal-Wallis $H$-test, $* * * p \leq 0.05$

2018). However, in this study, the educational level of the farmers was not found to affect farmers' willingness to establish a renewable energy cooperative. This can be interpreted as farmers at every level of education being willing to establish a renewable energy cooperative, regardless of their educational levels. Agricultural income was indicated as a distinctive factor in adaption of renewable energy (Tate et al. 2012). However, in this study, agricultural income was not identified as a distinctive factor $\left(\chi^{2}=7.098, d f 5, p=0.213\right)$. Like educational level, this case can then be interpreted farmers at every level of income being willing to establish a renewable energy cooperative, regardless of annual agricultural incomes.

Consequently, the barriers and drivers for establishing a renewable energy cooperative with farmers were discussed in Table 3. Accordingly, the drivers of establishing an energy cooperative were (i) high social acceptance, (ii) presence of young farmers, (iii) strong farmer-agricultural organization relationships, (iv) using the internet to access knowledge, and (v) farmers' land ownership. On the other hand, the barriers for establishing an energy cooperative were (i) financial barriers (high interest rates, low farmer income, and lack of equity capital), (ii) technological barriers, (iii) bureaucratic barriers, (iv) the difficulty of being in cooperation of all energy stakeholders, and (v) lack of a sectorally qualified workforce.

Table 3 Drivers and barriers to establishing a renewable energy cooperative by farmers

Drivers

High social acceptance

Presence of young farmers

Strong farmer-agricultural organization relationship

Using the internet to access knowledge

Farmers' land ownership

Barriers

Financial barriers (high interest rates, low farmer income, and lack of equity capital)

Technological barriers

Bureaucratic barriers

The difficulty of all energy stakeholders to cooperate with each other Lack of sectoral qualified workforce 


\section{Conclusions and recommendations}

It is important organizing education programs for farmers about climate change. By this way, their awareness could increase about climate change, and their capacity could be developed to make economic and environmentally sustainable decisions. Based on the present findings, the willingness of farmers to receive such education programs will make it easier. Education programs about climate change can be in the form of farmer meetings or seminars. It may be useful to make use of mass media for this. Such educations will generate awareness about the significance of renewable energy use in agricultural practices. The present findings revealed farmers' willingness to use renewable energy. Rather than acting individually, farmers should act collectively to benefit from renewable energy sources. The present findings revealed that farmers were willing to establish a renewable energy cooperative. Analyses in this study revealed significant information about what to consider in future planning processes. This information is quite significant for renewable energy cooperatives to be established in the future. In this sense, socioeconomic characteristics of farmers were highly significant. For instance, farmers' age, frequency of visits to agricultural organizations, internet use to reach information, land size, and annual agricultural income and the province they live in were identified to be distinctive factors that need to be considered in future planning for renewable energy sources. Determination of community acceptance of renewable energy in other regions of Turkey is important. This can guide policymakers in promoting renewable energy. In addition, stakeholders such as ministries, municipalities, non-governmental organizations, and associations should take the initiative to establish an energy cooperative in the region. After training of these stakeholders about renewable energy, the knowledge level of farmers will increase. Increasing awareness of renewable energy in the community will be a start for farmers to establish a renewable energy cooperative.

However, it is also important to overcome the barriers of establishing a renewable energy cooperative. Policymakers should establish policies to overcome these barriers. In this context, suggestions may be financial incentives should be increased, and the collateral conditions of banks should be improved. Policies to increase farmer incomes are also needed. National equipment production should be expanded. Thus, technological barriers can be partially overcome. In order to overcome bureaucratic barriers, bureaucratic procedures in approval, execution, and expropriation of projects should be prioritized and accelerated. Legislation should be streamlined. In addition, a platform can be created to bring together all stakeholders. So the process can be handled more practically. In addition, employees who are qualified in subjects such as accounting, informatics, and energy and who will work in the cooperative to be established should be employed in cooperatives.

\section{Declarations}

Conflict of interest The author(s) declare that they have no competing interests.

Ethical statement In the study, the participants were informed that the survey data will be used for scientific purposes. The survey was conducted with the necessary permissions from the participants. In addition, other ethical rules were taken into consideration in the study.

\section{References}

Al Katsaprakakis D, Voumvoulakis M (2018) A hybrid power plant towards $100 \%$ energy autonomy for the island of Sifnos, Greece. Perspectives created from energy cooperatives. Energy 161:680 698. https://doi.org/10.1016/j.energy.2018.07.198

Angelopoulos D, Doukas H, Psarras J, Stamtsis G (2017) Risk-based analysis and policy implications for renewable energy investments in Greece. Energy Policy. 105:512-523. https://doi.org/10.1016/j. enpol.2017.02.048

Anonymous (2020) Türkiye'de yenilenebilir enerji kooperatifleri. Sosyal Ekonomi Bloğu. https://sosyalekonomi.org/turkiyede-yenilenebilirenerji-kooperatifleri/ Accessed 15 Sept 2020

Batley SL, Colbourne D, Fleming PD, Urwin P (2001) Citizen versus consumer: challenges in the UK green power market. Energy Policy. 29(6):479-487. https://doi.org/10.1016/S0301-4215(00)00142-7

Beckman J, Xiarchos IM (2013) Why are Californian farmers adopting more (and larger) renewable energy operations? Renewable Energy. 55:322-330. https://doi.org/10.1016/j.renene.2012.10.057

Bender M (1999) Economic feasibility review for community-scale farmer cooperatives for biodiesel. Bioresour Technol. 70(1):81-87. https://doi.org/10.1016/S0960-8524(99)00009-7

Beyaz A, Onurbaș Avcıoğlu A, Dayığlu MA, Türker U (2017) Tarımsal üretimde enerji verimliliğinin planlanmasi ve sağlanması. http:// www.yegm.gov.tr/verimlilik/sunum2017/8.Bildiriler/Tar\%C4\% B 1msal\%20\%C3\%9Cretimde $\% 20$ Enerji\%20Verimlili\%C4\% 9Finin\%20Planlanmas\%C4\%B1\%20Ve\%20Sa\%C4\%9Flanmas\% C4\%B1.pdf

Bilgen S, Keleș S, Sarıkaya İ, Kaygusuz K (2015) A perspective for potential and technology of bioenergy in Turkey: present case and future view. Renewable Sustainable Energy Rev. 48:228-239. https://doi.org/10.1016/j.rser.2015.03.096

Bilgin S, Akçay VH (2017) The role of financial and taxational incentives in renewable energy co-operatives on the policiy of sustainable development. 22 International Turkish Cooperative Congress, Social Economy Networks: Cooperation for Global Change. October 0507 2017, Turkey.

Bolinger M, Wiser R (2006) A comparative analysis of business structures suitable for farmer-owned wind power projects in the United States. Energy Policy. 34(14):1750-1761. https://doi.org/10.1016/j. enpol.2005.01.003

Borchers AM, Duke JM, Parsons GR (2007) Does willingness to pay for green energy differ by source? Energy Policy. 35(6):3327-3334. https://doi.org/10.1016/j.enpol.2006.12.009

Borchers AM, Xiarchos I, Beckman J (2014) Determinants of wind and solar energy system adoption by US farms: a multilevel modeling approach. Energy Policy. 69:106-115. https://doi.org/10.1016/j. enpol.2014.02.014 
Büyüközkan G, Güleryüz S (2017) Evaluation of renewable energy resources in Turkey using an integrated MCDM approach with linguistic interval fuzzy preference relations. Energy. 123:149-163. https://doi.org/10.1016/j.energy.2017.01.137

Capellán-Pérez I, Campos-Celador Á, Terés-Zubiaga J (2018) Renewable energy cooperatives as an instrument towards the energy transition in Spain. Energy Policy. 123:215-229. https://doi.org/10. 1016/j.enpol.2018.08.064

Çetin B (2008) Tarımsal finansman. Nobel Yayın, No: 1321, ISBN: 978605-395-118-6, Ankara.

Çetin M, Eğrican N (2011) Employment impacts of solar energy in Turkey. Energy Policy. 39(11):7184-7190. https://doi.org/10. 1016/j.enpol.2011.08.039

Craig B, Pencavel J (1993) The objectives of worker cooperatives. J Comp Econ. 17(2):288-308. https://doi.org/10.1006/jcec.1993. 1027

Debor S (2014) The socio-economic power of renewable energy production cooperatives in Germany: results of an empirical assessment. Wuppertal Papers. No: 187.

Dinler Z (2008) Tarım ekonomisi. Ekin Kitabevi Yayınları, Bursa

Downing M, Volk TA, Schmidt DA (2005) Development of new generation cooperatives in agriculture for renewable energy research, development, and demonstration projects. Biomass Bioenergy. 28(5): 425-434. https://doi.org/10.1016/j.biombioe.2004.09.004

Durmaz Ayanoğlu GG (2014) Dünya örnekleri ile yenilenebilir enerji kooperatifleri. Enerji Uzmanları Derneği Enerji Piyasası Bülteni, Say1:31. http://koop.gtb.gov.tr/data/53be78f6f293708e6804beae/ YEN\%C4\%B0LENEB\%C4\%B0L\%C4\%B0R\%20ENERJ\%C4\% B0\%20KOOPERAT\%C4\%B0FLER\%C4\%B0\%20EPDK\% 20MAKALE-04\%2002\%202014.pdf

Ek K (2005) Public and private attitudes towards green electricity: the case of Swedish wind power. Energy Policy. 33(13):1677-1689. https://doi.org/10.1016/j.enpol.2004.02.005

Everest B (2018) Türkiye'de kooperatifçiliğin nicelik, mevzuat ve kamu yönetimi boyutlariyla irdelenmesi. Third Sector Social. Econ Rev 53(3):1008. https://doi.org/10.15659/3.sektor-sosyal-ekonomi.18. 11.1027

Fang X, Yang Q (2019) Cooperative energy dispatch for multiple autonomous microgrids with distributed renewable sources and storages. In Smart Power Distribution Systems. Academic Press, pp 127-160. https://doi.org/10.1016/B978-0-12-812154-2.00007-9

Günaydın G (2010) Tarım ve kırsallıkta dönüșüm - politika transferi süreci / Avrupa Birliği ve Türkiye. Tan Kitabevi Yayınları, Araștırma Dizisi 8., Ankara.

Gürel A, Irmak E (2017) Cooperative model of energy producing and consuming in terms of social economic network panel data analysis. 22 International Turkish Cooperative Congress, Social Economy Networks: Cooperation for Global Change, October 05-07, 2017, Turkey.

Gürtürk M (2019) Economic feasibility of solar power plants based on PV module with levelized cost analysis. Energy 171:866-878. https://doi.org/10.1016/j.energy.2019.01.090

Hentschel M, Ketter W, Collins J (2018) Renewable energy cooperatives: facilitating the energy transition at the Port of Rotterdam. Energy Policy. 121:61-69. https://doi.org/10.1016/j.enpol.2018.06.014

Hufen JAM, Koppenjan JFM (2015) Local renewable energy cooperatives: revolution in disguise? Energy Sustainability Soc. 5(1):18. https://doi.org/10.1186/s13705-015-0046-8

IPCC (2014) Intergovernmental Panel on Climate Change. Fifth assessment report. https://www.ipcc.ch/site/assets/uploads/2018/02/AR5 SYR FINAL SPM.pdf Accessed 11 Feb 2020

IRENA (2020) International Renewable Energy Agency. Renewables, Costs. https://www.irena.org/costs Accessed 29 December 2020

Karaca M, Nicholls RJ (2008) Potential implications of accelerated sealevel rise for Turkey. J Coastal Res 24(2):288-298. West Palm
Beach (Florida), ISSN 0749-0208. https://doi.org/10.2112/07A0003.1

Karagöl ET, Kavaz İ (2017) Dünyada ve Türkiye'de yenilenebilir enerji. Siyaset, Ekonomi ve Toplum Araştırmaları Vakfi Yayını. Yayın No: $197 \mathrm{https} / /$ setav.org/assets/uploads/2017/04/YenilenebilirEnerji. pdf

Kaygusuz K, Türker MF (2002) Biomass energy potential in Turkey. Renewable Energy. 26(4):661-678. https://doi.org/10.1016/S09601481(01)00154-9

Korkmaz M (2018) Public awareness and perceptions of climate change: differences in concern about climate change in the West Mediterranean Region of Turkey. Appl Ecol Environ Res 16(4): 4039-4050. https://doi.org/10.15666/aeer/1604_40394050

Kruskal WH, Wallis WA (1952) Use of ranks in one-criterion variance analysis. J Am Stat Assoc. 47(260):583-621. https://doi.org/10. 1080/01621459.1952.10483441

Lee TM, Markowitz EM, Howe PD, Ko CY, Leiserowitz AA (2015) Predictors of public climate change awareness and risk perception around the world. Nature Climate Change. 5:1014-1020. https://doi. org/10.1038/nclimate2728

Li R, Wang W, Wu X, Tang F, Chen Z (2019) Cooperative planning model of renewable energy sources and energy storage units in active distribution systems: a bi-level model and Pareto analysis. Energy. 168:30-42. https://doi.org/10.1016/j.energy.2018.11.069

Li X, Li H, Wang X (2013) Farmers' willingness to convert traditional houses to solar houses in rural areas: a survey of 465 households in Chongqing, China. Energy Policy. 63:882-886. https://doi.org/10. 1016/j.enpol.2013.09.004

Ma C, Rogers AA, Kragt ME, Zhang F, Polyakov M, Gibson F, Chalak M, Pandit R, Tapsuwan S (2015) Consumers' willingness to pay for renewable energy: a meta-regression analysis. Resour Energy Econ. 42:93-109. https://doi.org/10.1016/j.reseneeco.2015.07.003

Mann HB, Whitney DR (1947) On a test of whether one of two random variables is stochastically larger than the other. Ann Math Stat. 18(1):50-60 http://www.jstor.org/stable/2236101

McBride G (2012) Agricultural cooperatives: their why and their how. Springer Science \& Business Media.

Meissner F, Haas A, Hinkel J, Bisaro A (2020) A typology for analysing mitigation and adaptation win-win strategies. Climatic Change. 160: 1-26. https://doi.org/10.1007/s10584-020-02681-x

Melikoglu M (2016) The role of renewables and nuclear energy in Turkey's Vision 2023 energy targets: economic and technical scrutiny. Renewable Sustainable Energy Rev. 62:1-12. https://doi.org/ 10.1016/j.rser.2016.04.029

Motyka M, Slaughter A, Amon C (2018) Global renewable energy trends. Solar and wind move from mainstream preferred. Deloitte Development LLC, London

Mwirigi JW, Makenzi PM, Ochola WO (2009) Socio-economic constraints to adoption and sustainability of biogas technology by farmers in Nakuru Districts, Kenya. Energy Sustainable Dev. 13(2):106-115. https://doi.org/10.1016/j.esd.2009.05.002

Newbold P (1995) Statistics for business and economics. Prentice Hall Inc., USA, p 1016

Panoutsou C (2008) Bioenergy in Greece: policies, diffusion framework and stakeholder interactions. Energy Policy. 36(10):3674-3685. https://doi.org/10.1016/j.enpol.2008.06.012

Paredes D, Loveridge S (2018) Rural electric cooperatives and economic development. Energy policy. 117:49-57. https://doi.org/10.1016/j. enpol.2018.02.035

Republic of Turkey Ministry of Trade (2017) Turkey cooperative report2016 . https://esnafkoop.ticaret.gov.tr/data/ 5 d 4417773313 b $87 \begin{array}{lllllllllll} & 4 & 4 & 3 & 0 & 6 & 5 & 5 & 4 & 5 & 2\end{array}$ 15fb10a7fe0bba07482ac9da277b5d35.pdf. Accessed 8 Mar 2020

Republic of Turkey Ministry of Energy and Natural Resources (2019) General Directorate of Energy Affairs, National renewable energy action plan for Turkey. https://www.eigm.gov.tr/File/?path= 
ROOT $\% 2 \mathrm{f} 4 \% 2 \mathrm{fDocuments} \% 2 \mathrm{fEnerji} \% 20$ Politikas $\% \mathrm{c} 4 \% \mathrm{~b} 1 \%$ 2fNational_Renewable_Energy_Action_For_Turkey.pdf Accessed 8 Mar 2020

Republic of Turkey Ministry of Energy and Natural Resources (2020) Information Center, Electricity. https://enerji.gov.tr/bilgi-merkezienerji-elektrik Accessed 12 Sept 2020

Rincon L, Puri M, Kojakovic A, Maltsoglou I (2019) The contribution of sustainable bioenergy to renewable electricity generation in Turkey: evidence based policy from an integrated energy and agriculture approach. Energy Policy. 130:69-88. https://doi.org/10.1016/j. enpol.2019.03.024

Roe B, Teisl MF, Levy A, Russell M (2001) US consumers' willingness to pay for green electricity. Energy Policy. 29(11):917-925. https:// doi.org/10.1016/S0301-4215(01)00006-4

Roesler T, Hassler M (2019) Creating niches-the role of policy for the implementation of bioenergy village cooperatives in Germany. Energy Policy. 124:95-101. https://doi.org/10.1016/j.enpol.2018. 07.012

Sagebiel J, Müller JR, Rommel J (2014) Are consumers willing to pay more for electricity from cooperatives? Results from an online choice experiment in Germany. Energy Res Soc Sci 2:90-101. https://doi.org/10.1016/j.erss.2014.04.003

Schreuer A, Weismeier-Sammer D (2010) Energy cooperatives and local ownership in the field of renewable energy technologies: a literature review. https://epub.wu.ac.at/2897/1/Literature_Overview_energy_ cooperatives_final_(2).pdf

Soboh R, Oude Lansink A, Van Dijk G (2012) Efficiency of cooperatives and investor owned firms revisited. J Agric Econ. 63(1):142-157. https://doi.org/10.1111/j.1477-9552.2011.00324.x

Soon JJ, Ahmad SA (2015) Willingly or grudgingly? A meta-analysis on the willingness-to-pay for renewable energy use. Renewable Sustainable Energy Rev 44:877-887. https://doi.org/10.1016/j.rser. 2015.01.041

Subbarao S, Lloyd B (2011) Can the clean development mechanism (CDM) deliver? Energy Policy. 39:1600-1611. https://doi.org/10. 1016/j.enpol.2010.12.036

Tate G, Mbzibain A, Ali S (2012) A comparison of the drivers influencing farmers' adoption of enterprises associated with renewable energy. Energy Policy. 49:400-409. https://doi.org/10.1016/j.enpol. 2012.06 .043

Topcu I, Ülengin F, Kabak Ö, Isik M, Unver B, Ekici SO (2019) The evaluation of electricity generation resources: the case of Turkey. Energy. 167:417-427. https://doi.org/10.1016/j.energy.2018.10. 126

Topkaya SO (2012) A discussion on recent developments in Turkey's emerging solar power market. Renewable Sustainable Energy Rev. 16(6):3754-3765. https://doi.org/10.1016/j.rser.2012.03.019
Turkish Statistical Institute (2020a) Greenhouse gas emission statistics (1990-2018). http://www.tuik.gov.tr/PreTablo.do?alt_id=1019 Accessed 25 Sept 2020

Turkish Statistical Institute (2020b) Electricity distribution and consumption statistics (1970-2018). http://www.tuik.gov.tr/PreTablo.do?alt id=1029 Accessed 25 Sept 2020

UNDP (2019) United Nations Development Program, Sustainable development goals. http://www.undp.org/content/undp/en/home/ sustainable-development-goals/goal-12-responsible-consumptionand-production.html Accessed 05 Mar 2020

Uslu YD, Kedikli E (2017) The role and importance of renewable energy cooperatives over sustainable development in terms of Turkey, 22 International Turkish Cooperative Congress. Social Economy Networks: Cooperation for Global Change. October 05-07, 2017, Turkey.

Viardot E (2013) The role of cooperatives in overcoming the barriers to adoption of renewable energy. Energy Policy. 63:756-764. https:// doi.org/10.1016/j.enpol.2013.08.034

Waibel H, Pahlisch TH, Völker M (2018) Farmers' perceptions of and adaptations to climate change in Southeast Asia: the case study from Thailand and Vietnam. Nat Resour Manage Policy 52. http://www. fao.org/3/a-i7931e.pdf. https://doi.org/10.1007/978-3-319-61194-5

Wüstenhagen R, Wolsink M, Bürer MJ (2007) Social acceptance of renewable energy innovation: an introduction to the concept. Energy Policy. 35:2683-2691. https://doi.org/10.1016/j.enpol.2006.12.001

Yavuz F (2005) Agriculture in Turkey. Ministry of Agriculture and Rural Affairs Publications. Ankara, pp 1-252

Yayar R, Kaplan C, Şimşek U (2014) Awareness on economic, social, and environmental effects of the global warming: experimental findings from Turkey. Bus Econ Res J. 5(3):81-95 ISSN: 1309-2448

Yıldırım M (2020) Tarımsal kooperatiflerin yenilenebilir enerji kaynakları farkındalıkları ve adaptasyonları: Çanakkale ili örneği, Çanakkale Onsekiz Mart Üniveritesi Lisansüstü Eğitim Enstitüsü Yüksek Lisans Tezi 65s 8(1):233-241

Yildiz Ö, Radtke J (2015) Energy cooperatives as a form of workplace democracy? A theoretical assessment. Econ Soc Eur Electron Newslett. 16(3):17-24 http://hdl.handle.net/10419/156056

Yildiz Ö, Rommel J, Debor S, Holstenkamp L, Mey F, Müller JR, Radtke J, Rognli J (2015) Renewable energy cooperatives as gatekeepers or facilitators? Recent developments in Germany and a multidisciplinary research agenda. Energy Res Soc Sci 6:59-73. https://doi.org/ 10.1016/j.erss.2014.12.001

Zoellner J, Schweizer-Ries P, Wemheuer C (2008) Public acceptance of renewable energies: results from case studies in Germany. Energy Policy. 36(11):4136-4141. https://doi.org/10.1016/j.enpol.2008.06. 026 